\title{
Hvad kasserne gemte
}

\section{Peter Seebergs arkiv på Hald Hovedgaard}

Peter Seebergs arkiv har til huse på Hald Hovedgaard nær Viborg, hvor det er placeret efter ønske fra forfatteren, der så den smukke bygning som et kulturelt mødested for forskere og forfattere. Det var Seebergs tanke, at papirerne skulle indgå som en del af et levende kulturmiljø, og arkivets placering på et sted, der danner rammen om et utal af kulturelle og litterære arrangementer, understreger ønsket om brug og virke.

Arkivets størrelse og manglen på orden har imidlertid gjort livet vanskeligt for forskere, som har ønsket at benytte det spændende materiale, der gemmer sig i kasser og skuffer. Og det var grunden til, at et tværinstitutionelt samarbejde mellem forskere fra Syddansk Universitet, Statsbiblioteket i Århus, Syddansk Universitetsbibliotek og Arkiv for Ny Litteratur blev iværksat med henblik på at skaffe midler til registrering af Peter Seebergs arkiv og Arkiv for Ny Litteratur (som er den anden halvdel af arkivmaterialet på Hald). Center for $\mathrm{Ny}$ Litteratur, som det tværinstitutionelle samarbejde under ledelse af professor Anne-Marie Mai valgte at kalde sig, søgte om midler hos Veluxfonden, og i maj 2002 vedtog fonden en bevilling til Centeret på to millioner kr. Arkivmaterialet blev fordelt således, at Syddansk Universitet og Syddansk Universitetsbibliotek varetager registreringen af Arkiv for Ny Litteratur, mens Statsbiblioteket varetager registreringen af Peter Seebergs arkiv.

\section{Registreringen af Peter Seebergs arkiv: Grovsorte- ring og finsortering.}

Den 7. august 2002 kørte jeg til Hald Hovedgaard for at afhente Peter Seebergs arkiv. Materialet befandt sig i et stort og uoverskueligt antal kasser, skuffer og arkivkasser, så af praktiske hensyn valgte vi at komprimere materialet. Ud af komprimeringen kom der 8 tætpakkede flyttekasser, 6 mindre kasser samt 50 små arkivkasser. Herefter gik turen tilbage til Statsbib- 
lioteket, hvor Kvindehistorisk Samling har stillet et kontor til rådighed så længe, registreringen forestår (halvandet år).

Det første skridt i retning af overblik og orden er en grovsortering af arkivmaterialet, og som arbejdet skred frem, viste det sig, at der var tale om en relativt enkel arkivstruktur. Ud af grovsorteringen kom der følgende hovedgrupper:

Manuskripter, korrekturer m.m. af Peter Seeberg.

Manuskripter, korrekturer m.m. af andre forfattere.

Bøger og artikler (publicerede) af Peter Seeberg.

Bøger og artikler (publicerede) af andre forfattere.

Oversættelser af Peter Seebergs værker.

Anmeldelser, artikler, opgaver m.m. om Peter Seeberg.

Bibliografier og registranter over Peter Seebergs forfatterskab.

Litterære priser.

Materiale omkring Peter Seebergs forlagssamarbejder, projekter, arrangementer m.m.

Breve til og fra Peter Seeberg.

Breve til og fra andre.

Personlige papirer, dagbøger, regnskaber m.m.

Fotos.

Blandet.

En oversigt over fordelingen af materialet - målt i flyttekasser - ser ud som følger:

Breve til og fra Peter Seeberg (3 fyldte flyttekasser)

Manuskripter, korrekturer m.m. af Peter Seeberg (2 fyldte flyttekasser)

Personlige papirer, dagbøger, regnskaber m.m. (1 fyldt flyttekasse og en mindre kasse).

Det øvrige materiale fordeler sig i nogenlunde lige store grupper. Den største gruppe er avisartikler om Peter Seeberg.

Efter grovsorteringen af arkivet gik jeg videre til finsorteringen af den største hovedgruppe: brevene. Der er skønsmæssigt tale om ca. 6000 breve, hvoraf hovedparten er breve til Peter Seeberg. Der findes kun et mindre antal breve fra Peter Seebergs hånd. Den første finsortering indebar en alfabetisering af brevene, og det er et relativt tidskrævende arbejde, da man ikke blot skal fordele brevene på bedste posthusmaner, men også tyde håndskriften. Man lærer dog efterhånden de fleste skrifttyper at kende og kan til sidst fordele brevene ved et enkelt blik. Der var imidlertid en restgruppe, 
som ikke lod sig verificere pga. utydelig håndskrift, og den næste opgave var nu at kontakte institutioner og familie. Bar brevet et brevhoved, var det relativt nemt at finde frem til vedkommende, og denne del af arbejdet førte mig vidt omkring (forlag, museer, biblioteker, foreninger og universiteter $\mathrm{i}$ indog udland). De øvrige breve krævede hjælp fra familie, og i den forbindelse fik jeg kontakt med Ditte Seeberg (Peter Seebergs yngste datter), som har ydet en meget stor indsats med verificeringen af breve.

Parallelt med dette arbejde tog jeg kontakt til de forskere, som måtte skønnes at have benyttet arkivet i de sidste 5 til 10 år og som i den forbindelse kunne have lånt materiale fra arkivet. Det betyder, at arkivet nu skulle være reetableret.

Nyt materiale er der dog også kommet til, idet Hanne og Ditte Seeberg har overdraget et større antal breve til arkivet fra bl.a. Thorkild Hansen, Ole Sarvig og Carl-Göran Ekerwald, og det skal de have hjerteligt tak for.

Det næste skridt var at lægge alle breve i læg (et læg for hver afsender) og samle læggene i papbind (såkaldte kapsler), og det er her registreringsarbejdet befinder sig pt. Herefter venter registreringen af det øvrige materiale, og når alt arkivmateriale er færdigregistreret og lagt i læg og kapsler, skal det inddateres i en arkivbase, som Statsbibliotekets IT-sektion har udviklet. Inddateringen betyder, at alle arkivalier får et nummer, og når dette arbejde er bragt til ende, vil registranten over Peter Seebergs arkiv være tilgængelig for alle forskere og brugere, der har adgang til en pc.

\section{Forskning}

Registreringen af Peter Seebergs arkiv er at række Seeberg-forskningen en hjælpende hånd. Arkivet bliver synligt og brugbart, og det bliver muligt at orientere sig i materialet uden først at skulle rejse til Viborg. Samtidig vil registreringen være med til at sikre et væsentligt og bredspektret materiale af $\mathrm{og}$ om en af dansk litteraturs store forfattere. Sidst, men ikke mindst, vil Peter Seebergs arkiv på Hald Hovedgaard bidrage med nye perspektiver på dansk litteraturhistorie og kulturhistorie i det 20. århundrede. Det skal blive spændende at se, hvad kasserne gemte. 
2 reget.

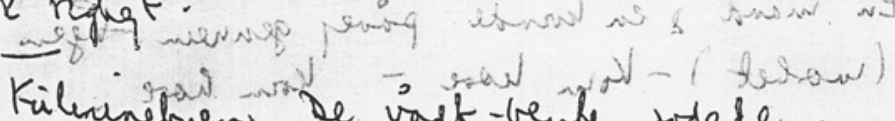
- Kunetyen. De vad-beuld wolete. Favet der bgges dyat undel.

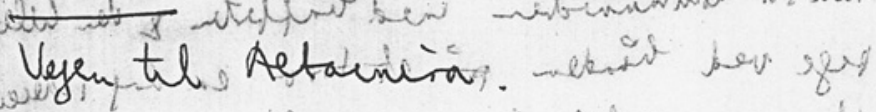

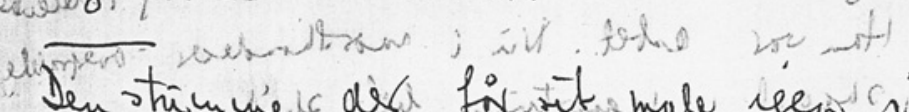
den stimkiev dica, fin sit male igew is

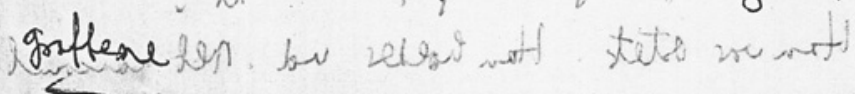

En mand \& en kinde pive/ gennein tajen (wohet) - Kow kore - Koun hare Men huir ar exate

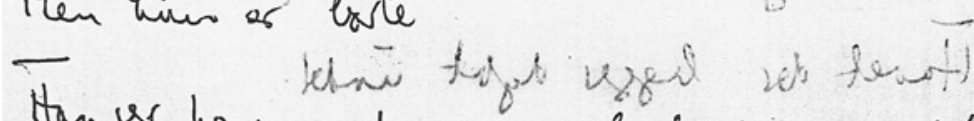

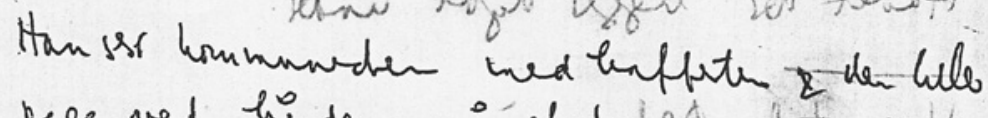

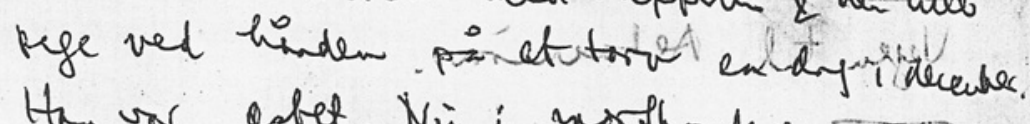

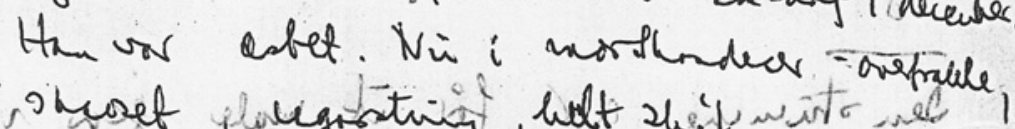

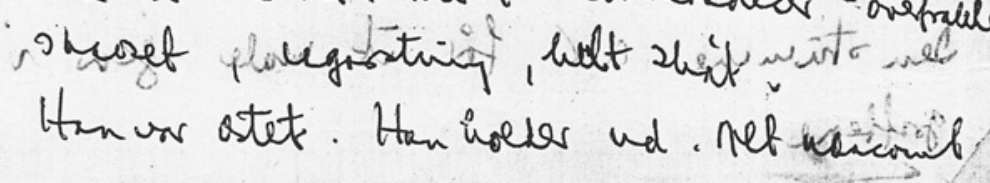

